\title{
大阪市小学校における校外行事の定着と 野外学習について
}

田中耕三・大森久治

1 はじめに

昭和30年第 3 次改訂社会科におけいて分野制が採用された際生れた単元、

「郷土」は，昭和 44 年の第 4 次改訂によって，「身近な地域」に改められた。 これによって単元のねらいは地誌学習に寄与するための方法概念としてとら える方向に重点を明白にした。いずれにしても単元誕生以来十数年の歩みを みるとき，その前進は遅々たるもので，第 4 次改訂後も特に進歩のあとはみ られない。

ところで，この種の単元が地理教育史上教育課程に誕生したのは，明治14 年の「小学校教則綱領」によって地理科が独立し，その内容に「学校近傍」 の学習が指示されたことによる。(筆者はこれを郷土地理と区別して「近傍地理」 と仮称している。

筆者はこの単元の指導の徹底が, 地理教育上重要な役割をもつものと考え, その推移に注目し，現場における実践例を探索したが，文献上では寡聞にし て, 明治29年東京高師付小における樋口勘次郎の片鳥山遠足」以外に接七な い。したがって明治時代におけるこのすぐれた単元の推移は詳かではない。 ただ，明治20年には府県地誌に先立ってその入門のため学習されたとの記録 はあるが，「改正教授術」にのべられたような実地の観察による生気ある学 習の実態はみられなかったように推察される。このことは，筆者が探索し之 た唯一の例である伊集院小学校の明治24年の学習ノートによっても一端がう かがえる。

筆者の一人大森久治は, 大阪市教育百年史の研究に際し，この単元に関す る大阪市における実践資料を探し出し, 学校行事としての野外学習における 定着への推移を確認した。また，筆者の一人田中耕三はこの内容を地理教育 史上より考察して学界に紹介した。本稿はこの内容について以後両者によっ て補正したものである。 


\section{2 校外行事の内容と定着}

1 ）各期の校外行事の特色

大阪市における教育先進校であり，沿革資料の完備した北浜小学校の校外 行事を中心に，行事の発端になったその他各校のものを一覧にしたものが 「第 1 表」である。これから，行事の推移を 3 期に分けた。

\section{(1) 明治初期の行事の内容}

この期は教育諸制度が未整備の「学制」から「改正教育令」のおわる（明 治18年) 頃まである。教育内容からみると，伝統的な寺子屋時代のものと文 明開化の輸入もの、混在した時期である。

「よみ・かき・そろばん」を中心にした寺子屋時代の教育にも，野外の行 楽的行事があり，「学制」期には専ら「ヤマユキ」（山遊，花遊，遊歩）とよば れる行事がもたれた。

\section{校外諸行事の年譜}

\begin{tabular}{|c|c|c|c|c|c|c|c|c|c|}
\hline & $\mid \begin{array}{c}\text { 遠 } \\
\text { 運 } \\
\text { 動 } \\
\text { 会 }\end{array}$ & $\begin{array}{l}\text { 運 } \\
\text { 動 } \\
\text { 会 }\end{array}$ & \begin{tabular}{|l|}
$j$ \\
花 \\
㝟 \\
袁 \\
足
\end{tabular} & 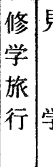 & 学 & $\begin{array}{l}\text { 校 } \\
\text { 外 } \\
\text { 授 } \\
\end{array}$ & $\begin{array}{l}\text { 東大組13区小学校 } \\
(\text { 足) } \\
\text { 北浜小学校 (M 8 } \\
19) \text { 愛日小学校 (M19～) } \\
\text { (O印) }\end{array}$ & $\begin{array}{l}\text { その他の大都市の小 } \\
\text { 学校 } \\
\text { (○印 })\end{array}$ & 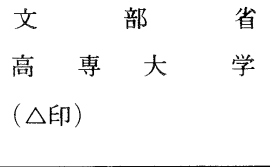 \\
\hline $\begin{array}{r}\text { 明 } 5 \\
6 \\
7 \\
8 \\
9 \\
10\end{array}$ & & $\Delta$ & $\mid \begin{array}{l}0 \\
0 \\
0 \\
0 \\
0 \\
0\end{array}$ & & $\begin{array}{l}8 \\
8\end{array}$ & & $\begin{array}{l}\text { 津村別院口シア皇子旅籠見学 } \\
\text { 䑝接校の開校式博覧会見学 } \\
\text { 難波村へ菜の花見に行く } \\
\text { 大阪博物場見学 }\end{array}$ & \begin{tabular}{|l|} 
南4区小が今宫方面へ遊歩 \\
南4区小が勝山へ遊歩 \\
南区瓦屋小町小王寺へ遊歩 \\
南区后屋町小博物場見学 \\
南区道仁小等博物場見学
\end{tabular} & $\begin{array}{l}\text { 紀元節創設 } \\
\text { 祝祭日画定される } \\
\text { 海軍兵学校で競斗遊戯会 }\end{array}$ \\
\hline $\begin{array}{l}11 \\
12 \\
13 \\
14 \\
15\end{array}$ & 0 & $\Delta$ & $\mid \begin{array}{l}0 \\
8 \\
8 \\
0\end{array}$ & & $\begin{array}{l}8 \\
8 \\
8 \\
8 \\
0 \\
0\end{array}$ & & $\begin{array}{l}" \text { " 後に梅田方面遊歩す } \\
\text { 天王寺「福や」へ遊歩す }\end{array}$ & $\mid \begin{array}{l}\text { 教育博物館への見学·遊歩 } \\
\text { 森小学校外歩行を行う }\end{array}$ & $\begin{array}{l}\text { 体操伝習所を設ける } \\
\text { 札㨪農学校遊戱会開催 }\end{array}$ \\
\hline $\begin{array}{l}16 \\
17 \\
18 \\
19 \\
\\
\\
20\end{array}$ & 0 & $\Delta$ & & $\triangle$ & 0 & & $\begin{array}{l}\text { 北浜修道両小学校合同運 } \\
\text { 動会 } \\
\text { 住吉公園において運動会 }\end{array}$ & $\begin{array}{l}\text { この年まで博物場見学つづ } \\
\text { く }\end{array}$ & $\begin{array}{l}\text { 大阪師範学校遊泳科設ける } \\
\quad " \text { 步兵操練」を行う } \\
\text { 東京大学運動会を催す } \\
\text { 体操伝習所を東京師範へ移す } \\
\text { 東師で行軍旅行を行う } \\
\text { 大師で修学旅行をはじめる。 }\end{array}$ \\
\hline
\end{tabular}


明治 6 年11月 3 日, 南大組第 4 区小学校では, 「各生徒引卒, 高津宮ヨ リ生国魂神社へ参拝, 夫ヨリ今宮吉野桜へ遊歩ス。取締役, 戸長, 教師生 徒覧護ス。途中時雨降テ混雑ス」これは天長節儀式を兼ねて今宮方面へ出 た記録である。

このような遊山的遠足は各校で行われた模様で, 明治 7 年 4 月 3 日（神武 天皇祭）に南大組第 4 区小学校では生国魂神社から御勝山へ，明治 8 年 4 月 16 日東大組第13区小学校 (後の北浜小学校) が難波へ, 同年および 9 年第 2 大区第 4 番小学校が天王寺方面へ遠足している。

このような伝統的な「ヤマユキ」に加えて，新しく見学的行事が行われる ようになった。これは当時の時代思潮であった文明開化によるもので，新し い知識を見聞によって吸収しょうとした一環と思われる。その最初は，東大 組第13区長山片平右衛門が，明治 5 年来日したロシア皇子の宿舎を特別許可 をうけて児童に見学させた行事である。

明治 5 年10月 17 日の北浜学校日誌法にロシアー皇子旅籠, 西御堂かざり 付择見御特許二付，生徒不残一覧招致行事」

これにつづいて，明治 6 年には，隣区の小学校開校に際して開かれた博覧 会に全校生徒が行ったり, 明治 8 年に大阪博物場ができ, 毎春 4 月に特別博 が開かれることになると，各校春の博物場見学が年中行事となった。その以 明治10年以後には大阪府の奨励もあって各小学校に普及して行った。

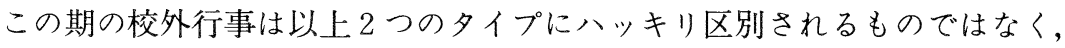
その中間的なものも多くみられる。すなわち, 同一日に午前は博物場見学, その足で郊外へ出て昼食をとり，英気を養うといった行事が普通となった。 の例として，明治12年 4 月18日北浜小学校の例をあげる。

明治 12 年 4 月 18 日の北浜小学校の遠足は，4 月11日に首席が人力車で, 「なんば一方より，生玉辺席借探索」するがうまく交渉できず，翌12日に学 校世話掛と 2 人で「北辺席借用」に人力車で行き,「博物場拝見二付, 引続遊 歩為致度，世話掛り鈴木又兵衛同道二而，席取極相成，北静観楼借受候。 尤，来る十六日と定。席賃三円外二金式十五銭，茶番壱人雇入，席元へ申付 付。但し，雨天日送り」と，16日の遠足が定まった。14日には「午後一時, 鈴木又兵衛出勤，運動所二於て，生徒・受持教員一統足揃候事」と遠足の 注意があった。しかし，「十六日，本日雨天二付，生徒博物館行十八日と 相定」まり, 再び「十七日, 本日午後, 鈴木又兵衛・松波小兵衛出勤, 運 動所二於テ，生徒・受持教員一統足揃候事」と注意した。18日は「午前十時 


\begin{tabular}{|c|c|c|c|c|c|c|c|}
\hline \begin{tabular}{r|} 
明 21 \\
22 \\
23 \\
\\
24 \\
25
\end{tabular} & $\left(\begin{array}{c}0 \\
0 \\
0 \\
0\end{array}\right.$ & & & & & 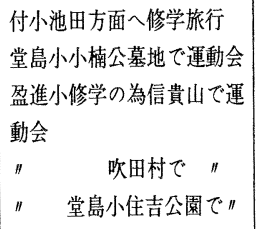 & $\begin{array}{l}\text { 紀元節歌を学校唱歌に採沢 } \\
\text { 等級制から学年制へ学年暦 } \\
\text { 小学校视日・大祭日儀式规程 }\end{array}$ \\
\hline \begin{tabular}{l|}
26 \\
27 \\
28 \\
29 \\
30
\end{tabular} & $\begin{array}{l}0 \\
0\end{array}$ & - & & & 始めて校庭運動会 & $\begin{array}{l}\text { 堂島小、小林遊園地で運動会 } \\
" \quad \text { 神戸市へ遠足運動会 } \\
\text { 滝川小、小林遊園地で " }\end{array}$ & \\
\hline $\begin{array}{l}31 \\
32 \\
33 \\
34 \\
35\end{array}$ & $\begin{array}{l}0 \\
0\end{array}$ & - & 0 & & $\begin{array}{l}\text { 展覧会、運動会を同日開催 } \\
\text { 創立式後運動会、校外遊觑 }\end{array}$ & $\begin{array}{l}\text { 船埸小水源地縋覧 } \\
\text { 堂島小奈良へ運動会 } \\
\text { " } \quad \text { 遠足運動会、沉愛山運動 } \\
\text { 会 } \\
\text { 沉愛小、四条㪞へ運動会 } \\
\text { " } \quad \text { 校庭運動会 }\end{array}$ & $\begin{array}{l}\text { 小学校に体操場設定義務づけ } \\
\text { 校長職確立、学年暦確立 }\end{array}$ \\
\hline $\begin{array}{l}36 \\
37 \\
38 \\
39 \\
40\end{array}$ & $\begin{array}{l}0 \\
0\end{array}$ & : & 0 & 0 & \begin{tabular}{|l} 
実地指教 $(3 \cdot 4$ 年大阪 \\
城) \\
\\
\\
校外指教（1４年）4 \\
泉布観
\end{tabular} & $\begin{array}{l}\text { " 堺水族館見学、運動会 } \\
" \text {. 校庭遊戱会 } \\
\text { 北大江小城南陸軍病院で運 } \\
\text { 動会 } \\
\text { 沉愛小校外授業 (住吉、天 } \\
\text { 下茶屋) }\end{array}$ & \\
\hline $\begin{array}{l}41 \\
42 \\
43 \\
44 \\
45\end{array}$ & & : & • & ? & \multicolumn{3}{|c|}{ 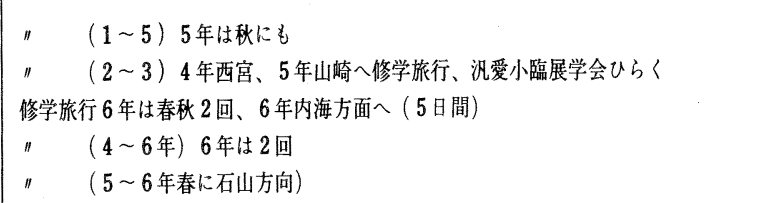 } \\
\hline
\end{tabular}


出門，博物所一生徒誘引，同所 遊歩所二而，生徒離散。次二豊 公神社へ参择, 北新地静観楼二 而遊歩，午后四時二十分より帰 校候事。」道・1斗で酒宴を開 いた。生徒295名は,大阪駅を出 入する汽車を見ながら食事をし た。学校留守人や, 本日不参の 学校関係者 13 人には, 池仁の弁 当に酒 2 升を添えて届ける心使 い。静観楼の勘定書には, 生徒 が割った茶碗12の代金もあった。 順は「北浜通り東へ，魚棚高 麗橋東詰南へ, 博物館入場。帰 $\eta$, 東堀北へ, 今橋西へ, 浪花 橋半より中之島南通り西へ, 豊

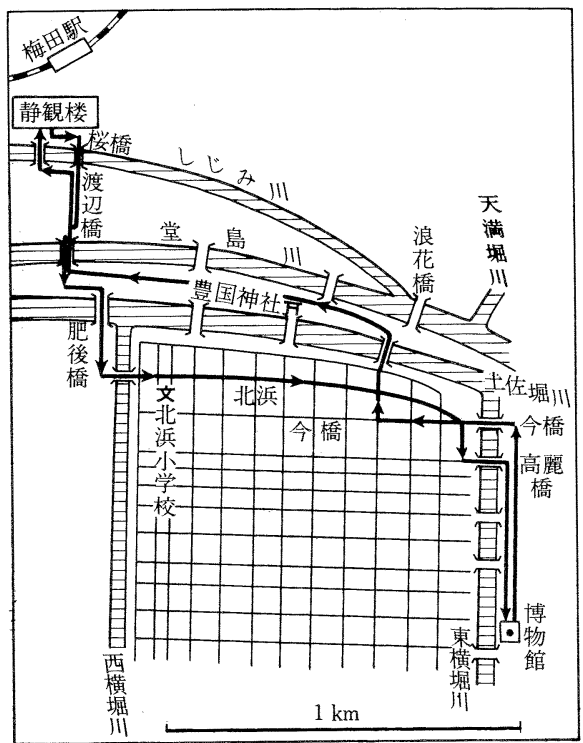
公へ参詣。渡辺橋北へ，新地裏町西へ静観楼へ入ル」㷌りは「裏町東へ, 桜橋・渡辺橋南へ，中之島南通東一，肥後橋南へ，北浜通り学校へ入ル」 と通った。その道順を地困に示すと上図のようになる。先頭に大旗をUる が之し，男子の下級生から，男生徒・夜学生，さらに，女子の下級生から， 女生徒・女子手芸生が続いた。各担任が列に付添うと共に小旗をもった学 校世話掛りや学校番も付添った。

第 1 目標の大阪博物場では春の大会で，各地の珍しい品物や産物が展示 してあった。豊国神社はやっと敷地（現地の中央公会堂のところ）が定ま り，仮本殿だけ建てられ，本殿建築のための砂持ちが今日行なわれていた。 そうして昼食場所の静観楼へ着くと，別行動をした戸長用掛や出納方も「 正午十二時より委員静観桜迄」着き, 訓導・助教から小使まで27人が, 池 仁の弁当と酒。

このような博物場見学引続き遊歩の記録は田衰, 中島, 肥後島小学校にも あり，こ、では博物場見学後, 浦江, 浜村, 上福島方面へ行くのが普通であ つた。このような博物場見学も明治 16 年 5 月の北区衣笠小学校の記録で一応 おわり，「山遊」の記録は明治13年で終っている。北浜小学校では明治 13 年 4 月25日に天王寺へ遊歩したのが山遊の最後となった。 
その後は春の行事として校内を日曜日に開放し，菓子を与えることにしてい る。

以上の上うな伝統的行事が衰えた原因には「昨22日薬師寺の花遊に出掛し 景状を聞くに，船中に 4 ～名の囃男を雇れ，ドンチャンのさわぎに紛れて， 老師某は酒に醉狂い....... と明治 12 年 4 月 23 日の朝日新聞に報道己れるよう な遊山的行事についての反省もあったようである。このように世評に耐えら れなくなった遠因は，近代学校の教育課程に根ざした教育的行事でなかった ところにあると考えられる。

次に, 体育的行事は明治 7 年海軍兵学校, 明治 11 年柇幌農学校, 明治18年 東京大学, 明治19年大阪府師範学校等, 高・専や大学において先行された。 大阪市の小学校では, 官立大阪師範学校 (大阪府師範学校ではなく国立のも の）の付属小学校では早くから体操をとり入れ，明治10年 2 月 14 日に明治天 皇は体操授業を天覧された。この小学校はのち，私立森小学校となるが，明 治14年 2 月には，郊外一の遠足に，太鼓，横笛の音楽に合せた行進を行った。 しかし，一般の小学校で体操が入ってくるのは昭和17年以後である。

\section{(2) 明治中期の行事の内容}

小学校令の出た明治19年からこれが改訂された明治33年頃までの期間を中 期とする。この期間は教育制度の整備期に当る。学校行事から及るとき儀式 的なものが確立するとともに校外行事である遊戯体操（運動会），野遊会 (遠 足）も小学校に普及してきた。この傾向を速めたものに明治 24 年制定の「小 学校祝日大祭日儀式規程」がある。その第 4 条に，「祝日大祭日二於テ八便 宜二従七学校長及教員, 生徒习率手于体操場二臨ミ若ク八野外二出于遊歔体 操习行フ等生徒ノ心情习快活ナラシメンコトヨ務ムへシ」との規定があった。

大阪市立公立小学校での運動会の初見は, 明治19年 4 月 7 日に北浜, 道修 両校が合併して行なったもので, 北浜小学校の日誌には, 「道修校生徒合併 ヨシ運動会ヨ為ス」とある。当時運動場がなかったので公園を借りて実施し た。このように校外で運動会を催すことにより，1 日行事として行楽地に弁 当を持参して開かれるのが一般であった。学校職員だけでなく, 学務委員か の学事関係者はもとより, 区役所の学務課長らの役人が同道することもあっ た。この遠足運動会の実施地は, 桜宮, 住吉公園, 東練兵場, 四天王寺, 四 条畷，北野村小林遊園地，奈良公園などがあった。

当時の様子を明治 32 年 11 月 4 日の堂島小学校の沿革誌から紹介する。

「奈良県奈良二於テ本校児童秋季運動会 7 催シ, 当日午前 7 時30分区会 
議長斉藤嘉七衛門, 同議員大島良吉, 学務委員長 森重助, 本区役所学務 課長 中條熊次郎, 課員 植村熊太, 庶務課員 菱田恒三郎, 校園職員 20 人 二テ引率シ, 又当日ノ救護トシテ, 校医 檜山内蔵太, 助手小瀧竹造, 附 添卜シテ使丁 6 名，児童附人 87 名，大阪鉄道二テ午前 10 時 30 分奈良着，各 名所旧蹟习巡覧シ同所二於テ種々ノ運動 7 為シ，同日 6 時一同友校セリ」 運動会の内容については，明治19年 5 月19日に行った北浜小学校の例では, 今日の小学校の運動種目の原型がみられる。

「授業后, 甲乙両体操生（初五ヨリ中一二至儿迄百五十人） ヨ率七, 桜 宮二第二運動会 7 為又。午后二時出校, 同五時三十分帰校, 生徒中幼少 ノ者アリタレトモ，一人ノ病ム者ナシ。運動会遊戯 第一次 旗拾七競争 数回 生徒八甲乙丙組/内二テ, 体長, 平均七ルモノニシテ, 㷌路二差支 ナキモノヨ撰フ。第二次変則旗拾七競争 数回 コレハ一時二多人数出来 ル法ニシテ, 此内二職員 ヨ変へタリシガ, 甚ダ愉快ヨ覚へタリ。第三次 二人三脚競争 数回。第四次馬遊競争 数回 コレ八, 今度我校新発明， 方ニシテ，先ツ旗ノ同色ナル者ヨ対立セシメ（都合十五組トナル）其原旗 ノ下ニテ，生徒 シシテ各自二馬（一人八馬トナリ，一人八先引トナリ，一 人八乗車トナリ, 先引ヨシテ旗习持タシムルノ方) 遊ノ組ヨ為サシメタリ。 第五次 旗戻シ競争 数回」

学芸的行事として, 明治20年頃から高等師範学校では修学旅行等が新しく 定例化されて行くが, 小学校では時期尚早で, 中期は上記のように運動会兼 遠足行事といった体育的なものが中心であった点が，前期と異なる。

\section{(3) 明治好期の行事の内容}

明治33年の第 3 次小学校令によって, 体操場の設置が義務づけられ, 中期 の遠足運動会は校内で行われるようになった。愛日（旧北浜）小学校におい ても，明治26年 5 月 1 日にはじめて校庭運動会が開かれた。他校においても 後年これにならったのは「第一表」の通りである。このような傾向から遠足 行事が分離されて実施されるようになり，さらに学芸的行事である校外学習 の萌芽をうながすようになった。

明治後期の校外行事の特色は, 学芸的行事である見学, 校外教授 (指教) 等 の実施である。すなわち，明治中期に杜絶していたこれらの行事が教育課程 の根拠を得て充実整備され定例化して行った。次に当時の教育的意識を論じ たものとして「沉愛教育」(第10号) 明治41年をあげる。 
校外教授は何の為に行るのか

百聞一見に若かずといふ如く, 児童に確実の知識をつけんと思はば, 只空の 話のみでなく実物を見せて惥に教へねばならぬ, 夫で学校の教授材料は成 るべく実物や標本を備ふることにして居れども，地理や歴史や理科に関す る材料は, 実地の場所に就きて十分観察せしむるが最早分りで且つ永く確 に記憶せしむる良法である。且つ時々野外に出でて新鮮の空気を吸ひ自然 の風物に眼を触れしむれば，児童も頗快感を覚に竹皮包の握飯も平日の美 味より一人うまく味し難苦欠乏にも堪へて精神身体をも鍛練する訳なれば, 一日の校外教授は知識身体何れの方面より見ても，格段の効能のあること なり。

然るに従来児童を野外に引率する場合は，児童のみでなく父兄方まで， やれ運動会だから明日の弁当は何々着物はどれどれなどと騒ぎ立てられ， 猶附添は丁稚か下女かなどと心配せらるるは, 前述の学校の目的とは全く 見当違にて，かかる附添は女中や丁稚の物見遊山となって校外教授には寸 事の利益なきみならず寧弊害となるのである。されば校外教授の時は父 兄諸君自同行して児童が野外に出た時収得する知識や, 吾子の健康状態や 気力などを査察せられんことを望みます。

この種の行事では明治31年船場小学校の「水源地従覧」, 明治36年愛日小 学校の「大阪城実地指教」からはじまり, 明治39年の沉愛小学校の「校外教 授」と名称も区々ながら学年別に実施することが定着して行った。愛日小学 校では「校外指教」とよび明治40年代には次のように実施した。

明治40年 $1 \sim 4$ 学年 泉布観

" 41 年 (春) $\quad 2 \sim 3$ 年 北野方面

4 年 梅田, 福島方面

5 年 梅田

" (秋) 5 年 新淀川, 博物館

” 42 年 (春) 2 年 十三堤

3 年 城東

$4 \sim 6$ 年 長野観心寺（修学旅行）

" (秋) 4 年 西宮付近

$5 \cdot 6$ 年 山崎方面

" 43 年 (春) $4 \cdot 5$ 年 玉手山方面

6 年 千谷方面 


$$
\begin{aligned}
& \text { 明治 } 43 \text { 年（秋） } \quad 4 \sim 5 \text { 年 瑞光寺 } \\
& 6 \text { 年 千早城趾 } \\
& \text { (夏休) } 6 \text { 年 内海方面 ( } 7 \text { 日間) } \\
& \text { ” } 44 \text { 年 (春) } 4 \cdot 5 \cdot 6 \text { 年 (方面不明) } \\
& \text { (秋) } 6 \text { 年 男山方面 } \\
& \text { " } 45 \text { 年 (春) } 5 \cdot 6 \text { 年 石山方面 }
\end{aligned}
$$

これらの内容は次項にあげるとして，明治 42 年春の行事にみられるように， 校外の見学を遠距離に求め,「修学旅行」のよび名で行われることが普及し てくる。

「修学」の名称は高等小学では明治20年の初頭から用いられてきた。すな わち, 盈進高等小学校は明治21年11月 4 日「東分校」男児习引率し, 修学, 為場浦二旅行シ一泊帰校ス」とある。また「修学旅行」という呼称は, 明治 27 年10月24日「秋季修学旅行ノ為分教場児童河内国十ル四条畷神社二詣儿」 が初見である。同校ではさらに 28 年 4 月汽車便により足を延ばしており，同 年10月にも実施して，秋季行事化した模様が察せられる。

尋常小学校での定着は明治 40 年 5 月の汎愛小学校の「第 2 学年の修学旅行 を提水族館に行う」が初見である。同校のこの行事は 39 年の「校外教授」と よんで実施したものをさらに呼びかえたもので後半両方の用語がみられる。 このよう併用は愛日小学校でもみられ，前記の「校外指導」のほか，遠距離 での汽車利用のものについては「修学旅行」の使用もみられる。

次に, 愛日小学校の修学旅行の様子を禀清書によって紹介する。

\section{修学旅行禀請書}

左記ノ通り来五月八日尋常科第四学年以上及七裁縫学校生徒/修学旅行 习挙行仕度候間此段禀請候也

明治 42 年 4 月 30 日

愛日小学校長高橋季三郎

兼愛日裁縫学校長

大阪市長 山下重威 殿

東区長 満野順

下記（項目のみあげる）

1 . 目的地及順路

2 . 歩行スベキ里程 
3 . 乗用物及乗用区間

4 . 出発帰校/時刻

5 . 監督教師氏名

6 . 学年及学級生徒数

7 . 費用総額及費用/出途

8. 教授事項

生徒一渡シ夕地図及解説書

2 ) 各行事の変遷と定着

(1) 体育的行事の定着花見遠足から運動会

初期の「学制」期においては，近代的な学校教育制度の出発ながら，その 内容は教科書, 教師, 教授法等も寺小屋時代のそれを継承するものが多かっ た。唯一の学校行事である「ヤマユキ」もその一つであった。教育課程から みるとき，体育的であるが多分に娱楽的，見学的な内容をもち総合的未分化 な行事であった。「教育令」の時期になると娛楽的な行きすぎが教師のため のものとなって世評の批判をあび消滅していった。中期になって教育制度 が基本計画期に入るにしたがい, 体育振興の方向に即応して, 運動的要素を 鮮明にした遠足運動会として復活して行った。当時の学校は, 運動場を具備 していなかったから，校外の公園等の広場で行われたので遠足的要素をもっ ていた。しかし, 後期に入って運動場は必備のこと、なったため, 体育行事 を中心にした校内運動会として定着し, 内容的にも今日の運動会の原型がで きるようになった。

\section{(2) 学芸的行事の定着}

一見学から校外指教, 修学旅行へ—

明治初期において，一般的に行われた「ヤマユキ」と併行して行事化した ものに見学があった。これは文明開化の時代思潮の学校行事化の一端で, 伝 統的な未分化のものではなく，知的啓蒙を主眼にした独立した行事である。 小学校令期において地理科の独立と内容の画期的な刷新によって生れた「近 傍地理」では野外の実地を学習の対象にしていたが, その文献は少なく, 学 校行事としての様子は全く不明である。東京高等師範学付属小学校の教育課 程では学校内外についてこの教授が実施されているが，校外学習の記録につ いては筆者は明治29年樋口勘次郎による「飛鳥山遠足」をみるにすぎない。 
大阪市の小学校では中期には学芸的行事はおとろえたが，後期にいたって すなわち明治39年汎愛小学校の住吉天下茶屋場水族館，浜寺方面への校外教 授をもって復活した。40年代には愛日小学校においても定例化した。これら の内容は，初期の総合的な校外行事ではなく，教科教育に基盤をもったもの であった。また，初期の文明的知識を外に求めるためではなく，教科内容の 実地検証の役割をもっていた。さらに，「近傍地理」のように，地理科学習の 入門的な教科単独行事でなく，国語，歴史，理科等の学習内容と関連した合 科的行事であった。

後期にはこの外, 修学旅行がおこり定着するとともに, 海水浴行事も行わ れ，現在の校外行事の全般の萠芽をみたといってよい。

\section{2 ．愛日・汎愛両小学校の「校外教授」の内容}

愛日，汎愛両小学校の校外教授の内容を，届出書㧍よび，「汎愛教育」から あげる。

1 ）愛日小学校の校外教授例（第 3 学年の例）

校外教授届 跬4

来 5 月 5 日午前 9 時ヨリ別紙教案/通り第 3 学年男女両学級男 70 女 83 八 校外教授 $习$ 北野附近二於于施行致候二付此段御届候也。但雨天順延本教授 八自分付添七一部/教授 担任可致二付此段申添置候也 明治41年 4 月 30 日

愛日尋常小学校長 高橋季三郎

大阪市長 山下重威 殿

尋常科第参学年効外指教案

一. 目的

亿村落ノ状態

口 春ノ季節二於ケル原野自然界ノ現象

八 水/性質 効用 循環/有様

右三項 観来セシメテ人生二如何十ル関係习有スルカノ大要ヨ会得セシメ 既教ノ修身国語ニツキテ見物指教タナシ之等智識 児童/身神/健康尹増進セシメントス 


\section{二 予備教授}

其ノ一 既授読本五 第一，第二，第三，第四ノ誦読話方ノ復習

1 村落ノ状況付夕リ楽シキ家庭ノ有様

2 春ノ景色 観察シテ自然ノ趣味 感セシメ且動植物ニ於ケル理科 的知識ノ一班 7 養

3 水ノ性質効用循環/理科的智識ヨリ人生二如何ナル影響セルカノ 問答

其ノ二

1 団体ノ趣味秩序ヨ重ンズベキ事相互ノ益ヨ計ル事

2 春季野山ノ自然ノ発生ニシキ農夫ノ工夫

労働者ノ勤労粒々辛苦ノ了解

3 十三附近ノ地理及沿革ノ大略新淀川菜花/名所

三 直観教授

1 春ノ時候八暑力ラズ寒カラズ四方ノ山ニ八霞カカリテ幕ヨ張ルガ如 ク鳥ハナキ花八笑七軟風徐二吹キ人心自怡和ヨ致スコトヨ了セシ メコノ好時節二当ッテ快楽 唯之ヨ貧耽シテ何等考察スル所十キハ実二之天恵习菓夕ルモノナ リ自然八吾々二対シ此ノ季節二最モ多クノ研究材料 ポスミレ菜花ノ花容形質色素成育等ノ知識 7 確実二ス

2 平野ノ展望等 ヨ追比セシム

3 水ノ性八低キニ流ルル故山間ノ溪谷ヨリ湧キ出テ流レ流レテ小川 集リ大川トナリコノ新淀川トナリ水ガ万物生育二及ボシ運輸交通 二及ボス影響

気候ノ循環が動植物二及ボス影響习説話シ吾人が無量ノ天恵 受シ幸福ニ生活シツツアルカラ悟ラシム

四終局

団体教材及自由観察事項 ルモノ八教室二備付佳作集二上ス

$2 ）$ 汎愛小学校の「校外教授」の実況（第 4 学年） 
同校「汎愛教育」第10号（明治41年）掲載記事から，校外教授の様子を担 察するため記事をあげる。

第四学年男女級校外教授の実況

五月二日午前八時学校 出テ, 同九時二城東練兵場ニツキ，少時土手ノ芝 生二憩七, 兵士ノ突貫ヤ, 散兵ナドノ操練 観夕，其勇壮ノ状，児童二発 奮尚武ノ気象 ヨ起サシメタデアラフ, 此時休鄎シテ市タ兵士ガ, 三三五五, ニコニコトシテ接近シ来リ，児童二何事カ物語リ打興ズル様，イカ二モ無 邪気デイト面白カッ夕。全十時頃ココタ立チ退キ, 畔道伝七二, 森/宮玉 造ヨ打千過キ，桃谷駅ノ東方ノ野原二来夕。此デ苗代二出合ッカ夕 7 , 前 学年デ授ケタコトヨ復習シ, 其傍二麦畑ガアッタ偶青空遙二天人ノ音楽, ヨーニ, 雲雀が囀ッテ市タカラ児童二向ッテ, 雲雀ノ巣八麦畑ノウチノ中 二造ルコト，其巣/容易二見当ラヌヨー二巧ニスルコトナドノ話ヨナシ， 顧ミテ金剛葛城生駒ノ諸山ヨ教へ，桃谷駅ニツキ将来授クベキ停車場ノ問 答ヨ行ヒ, ソレヨリ駅ノ附近恰好ノ丘陵デ弁当 7 使七, 中食後八児童 由二運動サセテ，オノガジン草花习摘ミ来ッテ尋ヌルモノニ八, 一々之ヨ 教へ夕。此時日光ノ直射が激イノデ, 木䕃ヨ探シテ暫ク避ケテ居ッ夕。 其中二空合ガワルクナッタカヨ, ココヨ去テ, 産湯二行ク途中デ茶畑ヨ見 出シタカラ，茶園ノ有様茶摘ノ模様ナドノコトヨ授ケ夕。夫ヨリ高津宮址 二向七其由来习授ケ夕址畔ノ実景习写生セシメ, 其カラ高津神社二詣ヅル 筈デアッタガ。カノ空模様ノ益々険悪ナッ夕ノデ, 直チ二帰校シタノ八, 午後三時デアッ夕。校内運動場二整列シ, 校長ヨリ今日ノ校外ノ課業ノ有 益デアッタコト及ビ運動後ノ注意ヨ与へテ各自二解散セシメス

次に，生活の手記により当日の様子を理解するために文献をあげる。

\section{第四学年校外教授ノ様子}

五月二日八第四学年男女生ノ校外教授デアッタカラ, 私等八, 勇ンデ学 校へ来夕。ソシテ, シバラク, 遊ンデキルト, マモナク，鈴ガナッタノデ, 会場ニアッマッテ唱歌ノ練習ヨスマセ，八時二十分コロ二学校ヨ出テ淡路 町ノ浜マデクルト，第二高等ノ生徒ト出合ッ夕，タブンコレモ校外教授 スルノデアラウト思ッタ。ソレカラ, 思案橋尹渡リ, 大手通习一筋二馬場 ヨ通リ, 城東練兵場へ行ッ夕。四方ヨナガメルト, 東ハ, 山デアッテ, 南 
八油菜ガ一面ニサイテ多。又，西八汽車ガシジュ一通ッテ市夕。北八歩 兵ナドガ, 演習ヨシテ多。私ラハ, コレタ見ナガラ休ンデ練習帖二学校 ヨ出テカラノコトヨ書イタ。シバラクシテ後, 野原ヤ村ノ中ヨ通ッテ年ル ウチニ, 仁丹ヤニッケルナドヨコシラへテキル工場 道ノワキカラ見ナガ ラ, コンド八ヒロイヒロイ野原へ出夕。麦八青青トナミタナシタヨーニツ クラレテキル。又, 黄㐰菜ノ花八今ヨサカリトサキソロッテキルノハマ コトニヨカッタ。ココデ又練習帖二色々ト書イ夕。ソレカラボチボチトア ルイテキルウチニ, モミヨマイテアル苗代ヤ麦ナドヨ見テ, ヒバリノスノ コトモ話ヨシテモラッタ。又, 双子山ヤ，金剛山や，キ兵ノ年ル所ナドタ 遠クカラ見テソレラヨ書キトメ夕。豊川稲荷ヨヌケ桃山停車場ノ前习通リ 又アトガへリヨシテ岡ヨコへ松林ノ中ヨヌケテ, ソコデシバラク休ンダ。 ヤガテ十一時ニナッタノデ馬場先生ヨカコンデ, ベントーヨ食ッ夕。中中 オイシクアッタ。人ハコノヨーニ動イテカラ物タタベタラ, マッ゙イ物モ味 ガヨイト思ッ夕。ゴハンガスンデカラ, 旗トリヤ, 鬼ゴトヤ, イクサゴト ナドヨシテキルト笛がナッタ。ソレハ先生カラ色色卜話がアッタノデアル。 一時ゴロニ空が曇ッテ来夕ノデ, 軍歌ヨ歌ッテ帰リ道ニツイタ。桃山中学 校ノ北デ茶ノ木 $タ$ 見テ，植物園二入リココデ又書イタ。ソレカラ産湯ノ稲 荷ヨ通ッテ大キ十洞穴ヨ見テ桃山ヨコエ仁徳天皇ノ御リヨーヘマキッ夕。 チョットオ八カノモヨーヨ書イテ上本町 校へカヘッ夕。時八三時スギデアッタ。ソコデ校長先生カラ話がアッテ, ミナ八家ニ帰ッ夕。コノ日八大層ユカイデアッ夕。

\section{3 ）愛日尋小学校「校外指教」の例（第 5 学年）}

\section{届出前文略}

来ル24日午前 9 時ヨリ別紙教案ノ通リ，第 5 学年男女両学級 1 校外教授 梅田付近二於テ施行可致候問此段及御座候

追テ教授八自分付添七監督及上一部/教授 $\ni$ 担任可致候二付，為念此段御 添候也

尚，当日雨天八節八順延／筈二有之候付此段併申候也

明治 41 年 4 月 21 日

次に，「校外指教案」をあげる。 


\section{尋常第五学年 校外指教案}

1 . 目的

春ノ季節二於ケル自然界ノ現象卜自然物卜尹直接二観セシメ，人間生活 上関係スル本項ノ多ク八理科/知識ニ基クコトノ大要 7 自得セシメ，既 教授/事項（修身，国語，理科，地理，歴史等）二就キ，実地二指摘啓 蒙シ, 一層明瞭確実ナル知識卜為ス卜共二, 未教授卜シテ, 次二来ルベ キ季節二関連セ儿教授材料ノ採取卜観察卜 二際シ，児童ノ直観ヨシテ明膫十ル理解，㷌納二資シ兼テ身体ノ健康心 意ノ快活ヨ期スルニ在り

\section{2. 予備教授}

既教授ノ事項ニシテ郊外教授二関連スルモノ八出発教室二於テ復演シ置 キ, 実施当日雑駿ナル児童ノ直観ヨシテ断片的散漫二流ルル弊ヨ予防シ, 実際二解釈セシムべキ事項习左/如ク限定ス。

団体的精神/発揮。規律秩序/実現。同情心/実演。(修身科)。春季, 自然現象及び自然物ノ発生。

\section{3. 直観教授}

農夫ノ勤労。身体健康保持法 (国語科), 市町村の地勢区分。山・川・ 谷) 勢情。平野田畑/効用（鄉土的地理）十三村付近/沿革, 十三橋故 事 (郷土的歴史)。油菜の性情蝶ノ特質, 及ビ油菜卜蝶卜ノ関係（理科）

\section{3 . 直観教授}

春ノ野山ハ一面ヨリ観レバ人間一年間ノ遊興ノ季節ナリ。故二学校二於 テ施行スル春季/郊外直観教授モ季節柄往々一日程ノ遊楽二陥り易キモ ノナレバ，本校細目八国語科トシテ八春景ノ実践味ヨ知ラシムルト共二, 地理, 歴史, 理科/実地教授二連結スベシト注意セラル。依テ本案八コ ノ意习体シ予備教授ノ項二於于連結事項八概説セシモ尚木元来，本教授 八多ク/場合其/教材夕ル物件カ部分指教ヨリ入リテ児童/知識二一, 系統习与人全体/概念二帰納七シムルモノナレバ, 結果/支離滅裂二流 ルル弊习救ハンガ為メ，特二各児童二教材ノ採取ス分与ヨナシ, 観察ノ自由习得セシメ以テ児童自身二研究ノ興味ヨ起サシメ理会ヨシテ 
容易ナラシメントス。

(1) 教材 豌豆

(2) 教材/要項

(1) 花ノ形状 $=$ 旗弁 1 ，翼弁 2 ，龍骨弁 2

(2) 葉ノ形状 $=$ 羽状複葉, 先端ノ三個

若ク八小葉八巻䫏/必要アリ

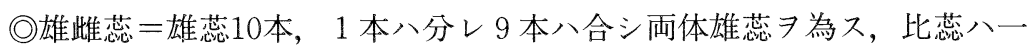
本ニシテ先端二細毛アリ

（3）全体ノ花ノ形状二蝶形ヨナス，故二此種二嘱ス

(4) 同種類二藤，すみれ，れんげそう等

4 . 結果/処理

一行市街地ヨ離ルレバ，隊伍ヨ解キ各自観察採取自由二与へ途二於テ見 聞シタル農夫ノ勤労貧民ノ状態等多方面二現ワレタル道心的行為二対シ テ八，教師八適ナル明知 7 加一勤メテ児童ノ判決処分二任シ後二来儿修 身材料二利用ス, 実施当日得シメル児童ノ観察七ル雑感事項八翌日教室 二於テ順序正シクロ述セシメ経方ノ材料二供ス

当日実施教授シタル事項八児童各自手帳二筆記セシメ置キ, 翌日思想整 トンノ上学校ヨリ配付スル別紙二記入呈出セシメ以テ郊外教授ノ成植物 トナス。

五学年 愛校 江田丑三郎

藤井重 孝

4 月18日

間 届出の名称は, 校外と郊外の二様になっている。また, 届出と教案 によって同一行事に 2 様を使っていることもある。

\section{3 校外指教の考察}

1）教育課程からみた意義

明治14年の「小学校教則綱領」まではの教育課程は，文部省の大綱によっ て府県あるいは学校の独自性が認められていた。また，教員養成や教科書に ついても，「近代教育の創始期」にあたっていたので，学校現場における教 
育の実態は様々であった。

大阪府の教則および地理に関する内容を図表にすると「第 1 図」のような 変化をもっている。

この表のうち,「地理初歩」と註5)と管内地理」は（誈6) 提として位置づけられている。「近傍地理」䛨》 は筆者の仮称によるもので，前 二者の実施に際して不可欠な内容かつ方法論として「小学校教則綱領」に示 されたものである。この校外学習による身近な地域の観察学習による内容を， 書物主義にかたよった「管内地理」と区別するためにつけたものである。

この単元は明治33年の第 3 次小学校令の改正において, 管内地理(郷土地理) の廃止とともに消滅した。しかし, この学習の方法論上の意義は, 国語科に ゆだねられた。愛日小学校の明治 40年代の「校外指教」は，この主 旨をくむことは，実施教案の「直 観教授」の中に，「本校細目は国 語科にして……流ルル弊习救ハン ガ為メ云々」とあることにあらわ れている。こ、に, 愛日小学校の 明治後半の見学, 修学旅行ならび に校外指教等が定着する教育課程 上の意義が認められる。

次に,「校外指教」の内容が単 に地理科だけを見ざしたものでな く, 国語科, 理科, 歴史科等の総 合的な内容をもっていること，さ らに本行事が全人教育的な心身の 健康の増進, 道徳心, 心意の昂揚 を目ざしていることは, 明治10年 代の「近傍地理」とは異なる。

2 ）地理教育史からみた意義

(1) 校外指教の地理的内容と考察 A 3 年の北野方面の内容

○ 日好の中に……村落の様子,

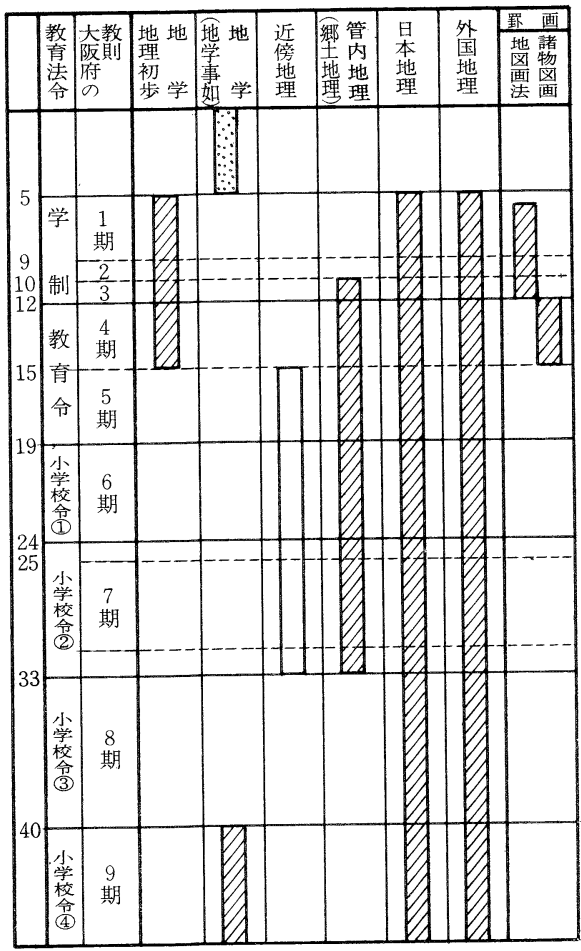

第 1 図大阪府教則による地理科の内容 
原野の自然界の現象

○予備教授の中に……村落の状況, 農夫の工夫, 十三付近の地理

○直観教授の中に……河川の上流, 中流の形状, 運輸交通への影響, 川の形態

B 4 年の城東方面の内容

苗代の様子，耕作物の様子，生駒 ·金剛 ·葛城山の様子，停車場の問 答，茶園

C 5 年の梅田方向の内容

○ 理科教村の観察が主になっているが，「目的」の中に「既教授ノ事項 項（修身，国語，理科，地理，歴史等）二就キ実地二指摘啓蒙シ，一 層明瞭確実ナル知識トス云々」，とのべているように全科総合的な内 容を包括している。

以上の内容から，地理的な内容について，次のような諸点があげられる。

○観察対象や学習範囲は，何々村といった行政区画や，校下といった地 域に限定していない。

○北浜小学校の「校外指教」でとりあげた梅田，十三堤，福島，北野， 新淀川等は学校の所在地（東区北浜 5 丁目）から 6 籸の範囲である。

○一日行事として実施し，校長も同伴し指導した学年行事である。

○学習内容は教科学習に関係のある顕著な野外事業をとりあげている。 明治20年代の管内地理の羅列的な内容ではなく，むしろ明治10年代の 「近傍地理」に近い。

※) 明治14年教則綱領には，「……先学校近傍ノ地形即生徒ノ親シク目熬 シウル所ノ山谷河海等ヨリ説キ起シ……, 殊二地文ヨ授クルニ八, 努メ テ実施二就キ児童ノ観察力习養成スベシ」とある。

\section{(2) 郷土地理教育史上の 2 つの思潮}

地誌を同心円的構造としてとらえ，その中核に郷土をおく考え方は郷土教 育の伝統的，主流的な考えである。郷土地理教育史はこの立場から時代区分 と盛衰が論じられている。この考え方は，「郷土による郷土への教育」とい った言葉に象徴されるように，郷土を目的概念としてとらえる立場に近よる 傾向がある。

これに対して，身近な直観にうったえられる事業を地誌学習の前提して学 習させる立場，いわば方法概念として考之る立場がある。この両者の間には， 郷土地理といった共通性の内にも，微妙に異なる目的乃至方法論がある。後 
者は早くも明治13年，東京師範付属小学校の「実物科」にみられるが，制度 的には，明治14年の「小学校教則綱領」第14条によって明確に示された。明 治25年の東高師付属小の「教授細目」は後者の立場による実践内容を明確に している。

本稿では郷土地理（両者をふくめた広い意味）の歩みを両者の交替論的に とらえ，「校外指教」をみようとするものである。

A いわゆる郷土地理の発展と推移

この立場における盛衰の時代区分は多くの先学によってなされ，近年菊地 利夫氏は次の期をあげられた。 ${ }^{5}$

第 1 回隆盛期 明治14 33年

$$
\begin{array}{lll}
2 & \text { ” 昭和 } 5 \sim 20 \text { 年 } \\
3 & \text { " } & \text { 昭和 } 21 \sim 33 \text { 年 } \\
4 & \quad \text { 昭和 } 33 \sim
\end{array}
$$

$\mathrm{B} 「$ 近傍地理」の発展と推移

郷土とか自村あるいは管内といったまとまりの土地の地理を学習対象とす ることを目的とする地理に対して，身近な事象を地理学習の基礎としてとら えようとする考え方に，明治10年千田一十郎の次の文献がある。

「下等小学初納二用フル地理初歩 7 廃止シ, コレニ代ワルニ児童地理学, 第一着手二学校中二於テ先方位 学校近傍ノ地形ヨリ一村二及ホスベシ」……「殊二区内地理八生徒日二之ヨ 目撃シ常ニ之ヨ実践スルモノ多キが故二, 教師授業ノ時ニ方リコレガ国画タ 示シ, 兓々口授シ又時トシテ八学校退散ノ際或八時間余アルニ会八, 自ラ生 徒 $引$ 率シ, 実地二就テ丁寧二教示スル等の方術ヨ以テセバ，地誌 シメザルモ地理ヨ習熟スルヤ，必ズ迅速ナランノミ……

この提識は各府県の管内地誌略をつくる時流の発端期の注目すべきものと なった。このような進歩的な地理学習観は, 明治初期に輸入された直入観教授 の思潮によるもので，この理論的先駆者は高嶺秀夫に伊沢修二であり，その 実践者は東京師範付属小学校の白井毅，若林虎三郎である。

明治13年の東京師範学校付属小学校の教則には，「実物」科をおき，地理， 博物，物理などの基礎学習を目ざした。中でも位置の教授は進歩的なものが あった。）次のその一部をあげる。

下級第 6 級 学室内諸物ノ位置习測定シ其ノ略図习作ラシム

" 第 5 級 学室外諸物ノ位置ヨ測定シ其ノ略図ヨ作ラシム 
下級第 4 級 前級二同シ

"第 3 級 学校近傍ノ位置ヨ教授シ其略図ヨ作ラシム

" 第 2 級 区内の位置 教授シ其略図 7 作ラシム

" 第 1 級 東京市内ノ位置ヨ教授シ其略図ヨ作ラシム

若林, 白井の両氏は明治14年「地理初歩教授術略説」を出し, さらに, 同 16 年名著「改正教授術」を著わした。この内容は先の千田十一郎の主旨に似 ているがより明快に「近傍地理」の立場を論している。すなわち，その序論 から一部を次にあげる。

夫レ地理, 学夕ル概子遠隔ニシテ耳聞目撃スルヨ得ザルノ事項二係ルヨ以 テ精密ナル想像力二因ラズンバ充分二之ヨ理解スル能ハズ今想像力ナルモ ノ八観察セル諸事物ノ集合シテ成ルモノナレバ想像力ノ精密ナランヨ欲セ バ観察ヨ精確ニセザルベカラザルヤ明ナリ故二地理学ヨ授クルニハ先ヅ生 徒尹囲繞スル諸物二就キ之ヨ精確二観察セシムルヨ以テ始ムベシ

是二因リテ之ヨ観レバ「地理学, 第一歩即観察タ主トスル部分八最緊切二 シテ地理学ノ有効卜無益卜ハ多ク此教授ノ適否二関スルヨ以テ教師八殊二 茲ニ意ヨ注ガズンバアルベカラズ」

東京高師（元東京師範学校）付属小学校は, 明治14年実物科を廃止後も, 直観主義, 作業主義的なカリキュラムは一定している。明治25年の教授細 目は, さらにフリードリッヒ・ユンゲ派の生活共同体的自然観による思潮を うけ，経験主義，生活中心的な立場から教科課程を作成している8 第一 学年より地歴科を抢き, 直観的, 郷土科的な扱いからはじまり, 高学年では 理科教授との関連を密接にしている。

明治29年付属小学校において, 実施した樋口勘次郎の「飛鳥山遠足」は, 「近傍地理」を一歩す め, 合科的な時代思潮を背景にした貴重な文献であ る。や、長文であるが，愛日小学校の「校外教授」と比較する資料としてそ の一部を次にあげる。9

〔飛鳥山遠足〕

此の日午後の中に準備をと、のへんことのいそがはしければ，たぶ明日 午前八時迄に上野池の端に集合、同刻出発，午後三時頃同所へ引揚げて、 尋で解散すべきこと、弁当及び手帳を携帯すべきことを告げて帰しむ。

余は昼食後直に準備をかるて上野にはせ上野より徒歩飛鳥山に至れり。 行々考へたるは， 
（1）生徒に一葉づ >の地図を持たしめん，（実地と比較せしめて一に は地理を知るに便し，二には地図の見方を学ばしめん為に)

（2）不忍池を観察せしめん。

（3）東照宮, 五重の塔, 動物園, 博物館, 美術学校, 音楽学校, 図書館 等の位地を地図と対照せしめん。

(4) 諏訪神社境内にて，北豊島より，南足立に亘る田畑，其間に点経す る村落，其問に林立する煙突，其間に散在する製造所，其間を走る 鉄路等を看察せしめん。

（５）胞衣会社の前，茲にても前の看察を補はしめ，自己の位置によりて 物景の変化するを知らしめん。

（6）田端車場を見しめん。人口の大なるを知らしめん。（広衣四十間四 方許，深さ十間許の一大坑を，現に数名の工夫等が掘りつ、ありき。

（7）余は高等師範学校文学科の出身，尋常師範にて学びたる博物の知識 は，元至て浅薄なる上に忘れたる事多ければ，追々に研究せんと思 ひ，一週間前に，植物自然分科表などかひたれども未だ用をたさず。 路傍の草木，其名すら知らざるが多きを如何にせん。大森氏（当時 高等師範の研究科に在りき）に，同行を依頼せん。

（８）道灌山より王子に至る路にて看察せしむべきは茶, 大根, 麦, 蕎麦, 胡葍葡, 葱等の畑。肥料, 播種（麦）収穫 (大根) 等。

（９）山林局試験場を見るに，三百余種の樹木を扵べ植えて一々名を附し たり，大森氏を頼み得れば，此処を縦覧せしむ。

（10）飛鳥山にては，昼食，休息，自由遊戯をなさしめむ。

（11）生徒に余力あらば山下なる田戋を帰らむ。

（12）此道にて稲田，稲の収穫，㩰，粐，唐箕，師等の収穫用諸器具，大 根の洗條，木綿畑，蚉蚚，汽車，鉄道等を看察せしめる。 上野につきたるときは，鐘声十時を報じて，大森氏を訪子いとまな かりければ，参謀本部の二万分の一の地図，東京名所図絵及び宝 丹などをかひ帰りて，左の如き地図四十余枚を蒟蒻版にて摺れり。 十二時就得。(地図省略)

C 郷土地理の輪廻観と愛日小学校の「校外指教」の位置づけ

（a)輪廻観からみた郷土地理の変遷

「近傍地理」は明治10年代に近代教育思潮として移入された直観主義の教 授論にもとずくもので，地理教授の導入期に不可欠な単元であることは今日 
も変わりない。しかし，当時における教育諸条件の不備な中で，このような 近代的な方法が普及することは不可能に近いことは，昭和 40 年代の「身近な 地域」の扱いが遅々としていることからも明らかであろう。

明治20年代に入り, 地理入門としてのこの単元は, 管内地理, 府県地理と して普及して行った。海後宗臣は，この辺の事情について「……れらに明 らかな如く, 明治24年の小学校教則大綱は, 直観初歩教授を行うという精神 によって郷土に於ける教育内容との関係を非常に深からしめたのであって， 明治10年代より現われた直観教授の思潮がこの頃に我が国の教育教授の一般 を支配することになったのである」とのべている。 ${ }^{10)}$

筆者は，10年代の近代的な教育思潮の実践例を探索しているが，たまたま 入手資料にもとづいて先年，伊集院小学校の生徒の手記を報告したが，他に 文献上には「飛鳥山遠足」以外に例をみない。明治20年代の郷土地理につい て明治35年棚橋源太郎はその弊を次のように指摘した。

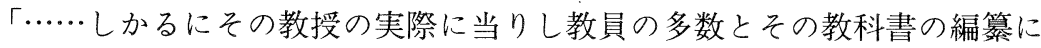
与かりしものの多くとは，彼の教則中に言へる郷土の地理，郷土の歴史に 関する意義を誤解し，郷土をもってその学校所在地の一府県一国を指する ものと解釈し, 各地方毎に各其の府県あるいは国の地理あるいは史談すな わち地方地理書地方歴史を編纂してこれが教科書に当てしめたり。殊にそれ 等府県の地誌史談の材料中には頗る専門的にして且高尚に過ぐる事項多か りき, この如くして郷土の意義を誤解したる当時の教員は, 郷土誌の趣旨 その教育上の価值，教授の方法等に関しても亦正当な意義あるはずなく， この種の教科書を用い，直ちに単にその書籍の媒介により知識を授けんと 試み, 毫も文部省の教則に要求せる所の学校の周囲, 児童の居住せる郷土 の自然および人事等日々児童の目撃し，接触せる事項を以って始むべきこ とに思い至らざりしが故に，児童は始めより毫も真の郷土的地理郷土的歴 史の教授により準備せらることなく, 安くんぞ直に能く一県下国の地理歴 史を正当に理解し想像することを得んや，……否単に児童のみ止まること

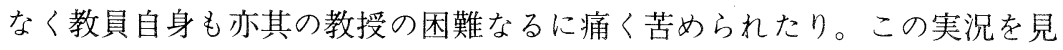
たる所の当時の教育家は一般に尋常小学校の児童に地理歴史を教授するこ とをもって到底不可能なり有害無益なりとの感を生じ，あるいは演説にこ れを論議する者の漸く多きを加え，終に当局をしてその弊を認め爾後尋常 小学校における日本地理，日本歴史を加了ることを容易に認可せざるに至 らしめ, 後明治33年に至り遂に小学校令の改正と共に郷土地理及び郷土歴 
史は全尋常小学校の教科より削除せられて23年における改正も空しく失敗 の歴史をのみ留むることとなりたり。

このように明治10年代の「近傍地理」は20年代には形式化し，初期の方 法的概念から目的概念の郷土地理化し，さらには直観を忘れ形式化文章化， 読本化した。このことは，先にあげだ海後宗臣の指摘と符合しない。このよ うにして, 直観主義の「近傍 地理」は明治33年小学校会の改正において, 本 単元が廃止の憂目をみるにいたる。

以上の考察から「近傍地理」は地形輪廻の原地形であり「管内地理」は近 年乃至老年期的存在で，両者は地形変化の周期を形成する傾向が観取される。 この単元の廃止された明治33年の直後再び回書した「近傍地理」は再輪廻の スタートをつくっているとみられないか。この第 2 の輪廻の終結期は，昭和 20 年のマッカーサー司令部の地理科の中止命令とする。

(b)「近傍地理」の再出発

明治37年東京師の「付属小学校規定」では, 明治33年第 3 学年における地 理・歴史・理科の基礎的陶治の項において，「……地理・歴史・理科ノ概念 ヨ授ク」とあったのを，明治37年には「児童ノ目撃シ得儿範囲内二於ケル地 理的・歴史的・理科的事項」と改为, 明治10年代の「近傍地理」にかえって いる。また明治 33 年大瀬甚太郎 (後の高師校長) は, 「教授法教科書」の中 の「郷土誌」において次のように論じている。

郷土誌

〔郷土誌ノ目的〕

其ノ目的八郷土ノ諸事物 ントスルニ在り。而シテ地理科二於テ最モ之ヨ必要卜スル故二, 地理科二 附属セシムルモノ多シ。抑郷土ノ事物ノ知識八新奇ノ事物 7 自己二連結セ シムル結晶的材料ニシテ, 実二諸般/新材料/識得二於テ, 類化的支柱夕 ルモノナリ。此ノ基礎 缺ケバ地理教授ノ如キ, 徒ラ二言語符号ノ記憶二 タラザルコト稀ナリトス。現今我ガ小学校二於テハ此ノ科习設ケザレドモ, 便宜読本教授卜連絡シ, 又特二地理ノ初歩教授トシテ是等ノ事項习授ケン 八蓋シ至当ノコトナルベシ。

〔郷土誌ノ材料〕

郷土誌ノ材料八必要十ラザルモノヨ省キテ模型的ノモノタ採ルベシ。 若シ又山河・溪谷等 7 実物二テ示シ難キトキ八, 庭中ノ小丘, 雨後ノ溝流 等ヨ利用スルモ可ナルベシ。而シテ郷土ノ諸事物八相互二関係ヨ有シテ有 
機的全体ヨ成久故二, 是等ヨ個々二授ケズシテ相連絡セシムベシ。此クノ 如クシテ後来，地理教授二要スル基礎的材料ヨ蓄積セシメ得ベキナリ。

〔鄉土誌ノ教法〕郷土誌八, 直観的二教授スル 要スル故二校外教授 7 行 ヨ良シトス。校外二テ観察セル所ノモノヨ簡単二説話シ, 或八又之ヨ校外 用黒板二図シテ持千帰リ，教室二テ指導的問答二依リテ，全教材

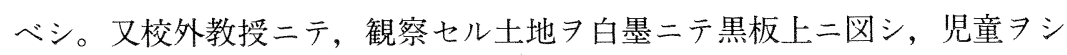
テ地図 7 理解スル知識 力 (抽象的想像) ヨ要スル故二, 特二注意シテ之ヨ授ケザルベカラズ。地 四习理解セシムル為メ二八, 亦郷土八高低図ヨ作リ, 或八湿潤セル沙土二 テ地形ヨ示又等/直観的方便ヨモ利用スベシ。

なお，明治36年高師付小の教授要目は次のように，直観主義の内容をもり こみ，10年代の思潮に継承している。

高師付小「教授要目」（明治36年 棚橋源太郎）

第 1 学年（週 1 時間）

家庭, 学校, 春, 学校, 花園, 夏, 秋, 家二住么動物, 冬, 教室, 学校 花園

第 2 学年 (週 1 時間)

春, 四季, 校内ノ花園, 秋, 学校, 教室, 室内ノ器具, 貨幣 第 3 学年 (週 1 学時間) （週 3 時間）

学校, 学校, 周囲, 聖堂/森, 夏/気象, 上野/丘, 藍染川/谷, 隅田 川, 市内の工業地, 冬, 気象, 市内ノ商業地, 交通機関, 家畜, 神田区 第 4 学年 (週 3 学年)

隅田川口, 品川町付近, 王子村付近, 板橋町付近, 目黑付近, 東京市,

新橋 - 箱根間汽車旅行, 房総半島一周旅行, 上野日光間旅行

(c) 愛日小学校の「校外教授」の考察

愛日小学校の全科目, 直観的な「校外教授」は，明治29年の「飛鳥山遠足」 を以って, 明治 10 年代の直観教授の思潮をうけながら, 明治 20 年代に移入さ れたユンゲ派の「生活協同体観」による総合的な色彩が加わっていることが 感ぜられる。それにしても，10年代に移入された思潮が大阪の先進校におい て明治40年代において定着したことは，寡聞をかえりみずいえば，教育思潮， 教育制度, 現場の実践の関係, わけても地方への普及は容易なら好のがあ るといわざるをえない。しかしながら, 愛日小学校の実践とその文献の保存 の意義は貴重なものといえる。 


\section{3 ）教授方法論からみた意義}

「校外指教」の届出書の項目は, 目的, 予備教授, 直観教授, 終局の 4 段 階をふみ，これはあたかも教室内の授業のように的確な計画性をもっている。 そして，内容は平素の教室内の学習と一体化した実証学習であることを明白 にしている。このような内容と計画性は，樋口勘次の「飛鳥山遠足」の前文 (準備と計画)，紀行，結果，結論の段階と対応している点が指摘できる。

野外の学習においては，自由観察，記録によるまとめなどの配慮がなされ ているほか，団体行動についての指導が行われている。この点からも，へル バルトの時代から, 社会的教育学, 自学主義乃至生活の自主性尊重の傾向の 尊重の一端がうかがえる。

4 ）理科教育史からみた後進性

「学制」期においては，地理的内容は理科的内容とともに読方・問答の中 で行われた。したがって伝統的な教授方法であるいわゆる，文字主義，暗記 主義の注入的教授法であった。

明治10年代の心性開発のために野外を観察することによって「近傍地理」 が発足したことはすでにのべてきたところであるが，このことは理科におい ても同様で実物に即して知的終索を目ざした。

明治19年の小学校令によって理科的内容は「博物」として統一されるが， 20年代に入って，ユンゲ流の「生活共同体」の思潮を移入し、「理科は『書物 を読む』のではなく，『自然を読む』ことを教える教科となる」の主旨のも とに観察，実験を中心とする学習指導法が確立して行った。

これに対して，地理科においてはその独立は理科より早かったが，10年代 の「近傍地理」は20年代には変質, 後退し, 明治33年の小学校令の改正で, 郷土地理の単元は廃止の運命を辿る。こ、で，野外の教材を扱う理科と地理 科が相反した道をたどることになる。したがって爾後校内施設，教室設備に おいても地理科は理科におくれをとったことは，今日まで，大学における実 験教科的時改措置がおくれたこと、軌を一つにしている。その責任は単に地 理教授者の責任だけでなく，地理学そのもつ性格や地理学者の責任ともいえ る。

\section{5 おわりに}

1. 寺子屋時代からうけつがれた「お花見遠足」行事は，「学制」期におけ 
る主な校外行事であったが，明治10年代前半に杜絶した。

2. 近代学校の教育計画にもとずく体育的行事である遠足運動会は，1）の 行事の未分化，総合的なものから分化したもので，明治20年前後からおこり， 明治20年代に定着した。また30年代には校内運動会として定例化し行った。

3. 学芸的行事のうち，見学は明治初期にみられたが10年代には中止された。 40年代にいたって, 教育課程を基盤にしてまた明治14年の「小学校教則綱 領」による近傍の観察はあまり普及しなかったようであるが，「校外教授

・校外指教」として復活し，先進校において定着した。

4. 北浜小学校における 3 ）の例は文献上, 樋口勘次郎の「飛鳥山遠足」に 類する稀少価值をもつものと思われる。この内容は10年代の「近傍地理」 の野外学習より変質し，20年代の理科教育の影響をうけていると思われる。 5 . 愛日小学校の「校外教授」の実践は, 第二期「近傍地理」の初期におけ る地方教育界に打ける先進的意義をもつものではなかろうか。

6.4）は，直観教育，思潮の移入後30年近い年月をへており，教育思潮の 地方への普及の困難性を思わせるものがある。

7 . 地理教授史における郷土地理の輪廻観は理科教授法史にくらべて後進性 を物語るもので，地理学の本質にもとずく教授方法の確立がこの克服の前 提として望まれる。

\section{〔註〕}

註 1 ）樋口勘次郎

明治28年東京高師卒。直ちに付属小学校訓導となる。明治32年「統合主義新教 授法」をあらわし, ヘルバルト派全盛時に終止符をうち, 児童中心, 自性, 自 発活動主義をとなえ時代の転機をつくった。彼の思想はパーカーによるとこ ろが大きいといわれる。

註 2 ）大森久治

昭和23年広島高師卒。第二師範付中をへて，大阪市教育研究所につとめた間， 大阪市教育百年史の資料収集に当り，研究所より，北浜小学校の資料を出した。 後年「明治の小学校」（S・48・泰流社）を刊行した。

註 3 ) 北浜小学校

明治 5 年東大組第 13 区小学校として開校, 明治 8 年北浜小学校と改称, さらに 19年愛日小学校と改現在にいたる。

本校の沿革誌並びに蔵書はよく整備され, 学界から高く評価された貴重な文献 
である。その一部は，大阪市教育研究所の紀要として刊行されている。

註 4 ）校外教授届

明治41年 3 月 12 日，学乙 109 号で「校外教授ノ為二市外二引卒スル場合二八，基

当日ヨリ一週間前二市役所へ申請書ヨ差出スへキコト」と達せられている。

註 5 ) 地理初歩

明治 6 年教科書として師範学校の編集で出版。45の府県で教則に使用を指示さ

れている。地理の術語の定義集のようなもので，抽象的な解説である。

註 6 ）管内地理

伝統的な道中物や往来物のかわって，明治10年前後から，郡や，府県地誌が

多く刊行された。内容は管内総覧的なもので，明治30年の前半まで多く刊行さ れた。

註 7 ）「近傍地理」田中耕三が，昭和41年の「郷土地理教育の一段階一（明治時代）」 新地理掲載において使用したもの。明治14年の小学校教則綱領の第14条にもと ずく，近傍の地形や人文事象について，実地の観察にもとずいて学習する内容 及び学習法をさしている。現在の「身近な地域」に近いもの。

註 8）「生活共同体」

板倉聖宣氏は,「生活共存体」とよんでいる。

\section{〔参考文献〕}

1) 田中耕三 郷土地理教育の一段階一明治時代一

新地理14卷 3 号 $(\mathrm{S} \cdot 41)$

2 ）拙稿 前揭 1 )

3 ）佐藤秀夫 学校行事の成立史 $(\mathrm{S} \cdot 43)$

教育 第229号 P 24 36

4 ）梅根 悟 社会科の歴史 金子書房 ( S · 29)

教育文化史大系 II P. 170 185

5 ）菊地利夫 地理学習の原理と方法 P. 193 198

金子書房 ( S · 35)

6 ）倉沢 岡朔 小学校の歴史 (第 1 巻) ( S - 年) P.993〜 4

7 ）川合 章 教授法史 前掲 4) P. 129 130

8) 板倉聖宣 日本理科教育史 P. 190 199

第一法規出版 (S.43)

9 ）梅根 悟 日本の新教育運動 金子書房 $(\mathrm{S} \cdot 27)$ 
日本教育史（東京大学講座）P．168～ 173

10）海後宗臣 我が国における郷土教育と其施設

11）棚橋源太郎 尋常小学校に於ける実科教授法（P．2023）

12）東京高師 東京文理大

創立60周年（P．336）

13）大瀬甚太郎 教授法教科書

14）板倉聖宣＼cjkstart前掲 8） P. 185 